Article

\title{
Comparative Proteomic Analysis of Differential Responses of Pinus massoniana and Taxus wallichiana var. mairei to Simulated Acid Rain
}

Wen-Jun Hu ${ }^{1, \dagger}$, Juan Chen ${ }^{1, \dagger}$, Ting-Wu Liu ${ }^{1,2}$, Martin Simon ${ }^{1}$, Wen-Hua Wang ${ }^{1}$, Juan Chen ${ }^{1}$, Fei-Hua Wu ${ }^{1,3}$, Xiang Liu ${ }^{1}$, Zhi-Jun Shen ${ }^{1}$ and Hai-Lei Zheng ${ }^{1, *}$

1 Key Laboratory for Subtropical Wetland Ecosystem Research of MOE, College of the Environment and Ecology, Xiamen University, Xiamen 361005, Fujian, China;

E-Mails: huwenjun@stu.xmu.edu.cn (W.-J.H.); chenjuanmn@xmu.edu.cn (J.C.);

liutw@xmu.edu.cn (T.-W.L.); martinsimon23@gmail.com (M.S.);

wangwenhua107@xmu.edu.cn (W.-H.W.); chenjuan2008@xmu.edu.cn (J.C.);

wufeihua@xmu.edu.cn (F.-H.W.); 1x19890818@stu.xmu.edu.cn (X.L.);

shenzj456@sina.com (Z.-J.S.)

2 Department of Biology, Huaiyin Normal University, Huaian 223300, Jiangsu, China

3 College of Life and Environmental Sciences, Hangzhou Normal University, Hangzhou 310036, Zhejiang, China

$\dagger$ These authors contributed equally to this work.

* Author to whom correspondence should be addressed; E-Mail: zhenghl@xmu.edu.cn; Tel.: +86-592-218-1005; Fax: +86-592-218-1015.

Received: 4 January 2014; in revised form: 5 February 2014 / Accepted: 17 February 2014 / Published: 12 March 2014

Abstract: Acid rain (AR), a serious environmental issue, severely affects plant growth and development. As the gymnosperms of conifer woody plants, Pinus massoniana (AR-sensitive) and Taxus wallichiana var. mairei (AR-resistant) are widely distributed in southern China. Under AR stress, significant necrosis and collapsed lesions were found in $P$. massoniana needles with remarkable yellowing and wilting tips, whereas T. wallichiana var. mairei did not exhibit chlorosis and visible damage. Due to the activation of a large number of stress-related genes and the synthesis of various functional proteins to counteract AR stress, it is important to study the differences in AR-tolerance mechanisms by comparative proteomic analysis of tolerant and sensitive species. This study revealed a total of 65 and 26 differentially expressed proteins that were identified in 
P. massoniana and T. wallichiana var. mairei, respectively. Among them, proteins involved in metabolism, photosynthesis, signal transduction and transcription were drastically down-regulated in P. massoniana, whereas most of the proteins participating in metabolism, cell structure, photosynthesis and transcription were increased in T. wallichiana var. mairei. These results suggest the distinct patterns of protein expression in the two woody species in response to $\mathrm{AR}$, allowing a deeper understanding of diversity on $\mathrm{AR}$ tolerance in forest tree species.

Keywords: acid rain tolerance; proteomic; Pinus massoniana; stress response; Taxus wallichiana var. mairei; woody plant

\section{Introduction}

Constant increase of human activities in recent decades results in some regions suffering from environmental pollution, such as acid rain (AR), especially in the fast developing regions of southern China [1,2]. To date, AR continues to threaten many sensitive ecosystems and cause detrimental impacts on local vegetation [3,4]. For instance, AR can induce necrosis and chlorosis in leaves of AR-sensitive plants and even structural abnormalities through damaging the cuticles of the epidermis and leaf mesophyll cells $[5,6]$. In addition, AR can also disturb the normal metabolism of plants and cause a decrease in photosynthesis, depression in plant growth and development, and even the death of plants in some extreme cases [7].

Pinus massoniana, a widely distributed coniferous species in southern China, has suffered seriously from AR in recent decades [8]. Severe defoliation of P. massoniana in several AR-affected regions of southern China was revealed in previous studies and the growth was significantly reduced under AR treatment $[9,10]$. Taxus wallichiana var. mairei, another conifer tree species, is distributed in adjacent regions that are also suffering from serious AR [11]. Physiological and biochemical changes and growth responses to AR have been reported in T. wallichiana var. mairei. The results suggest that T. wallichiana var. mairei is a resistant species to AR stress [12,13]; however the biochemical and physiological features and molecular mechanisms of such a distinction remains poorly understood. Analyzing protein expression changes under AR stress is a powerful way to reveal the molecular mechanism through a comparison between AR-sensitive and AR-resistant species.

Recently, by using a 2-DE-based proteomic approach, a set of proteins associated with: primary metabolism, secondary metabolism, protein stability and defense, photosynthesis and energy metabolism, etc., have been successfully identified and characterized, and may play important roles in mediating plant responses to AR for P. massoniana and Arabidopsis [14-16]. In the present study, a 2-DE and MALDI-TOF MS study was performed to identify the global changes in protein expression under AR treatment in P. massoniana and T. wallichiana var. mairei, which respectively represent AR-sensitive and AR-tolerant species. Furthermore, we also characterized the AR-responsive proteins, analyzed the functions of these differentially expressed proteins, and established the different responsive networks of metabolism in P. massoniana and T. wallichiana var. mairei under AR stress. 
The results of this study, providing different evidence from that evaluating the effects of AR stress on single tree species, could further enhance the current understanding of the protein changes underlying AR stress-related cellular and physiological responses between AR-sensitive and AR-resistant woody plants, and further dissect the different tolerance mechanisms of forest trees to AR stress.

\section{Results and Discussion}

\subsection{Results}

\subsubsection{Phenotype and Physiological Changes in P. massoniana and T. wallichiana var. mairei under AR}

In order to study the responses of woody plant to AR stress, P. massoniana and T. wallichiana var. mairei, an AR-sensitive and AR-tolerant tree species respectively, were treated with simulated AR (pH 3.0) for two months. First we investigated the detrimental phenotypical and physiological changes of these two species under AR stress. Morphological changes of both species are shown in Figure 1A, the chlorophyll content and net photosynthetic rate $(P n)$ of the saplings were also measured (Figure 1B,C). After two months of AR treatment, the significant necrosis and collapsed lesions were found in needles with remarkable yellowing and wilting tips in P. massoniana, whereas T. wallichiana var. mairei did not exhibit chlorosis and visible damage (Figure 1A). As shown in Figure 1B,C, the chlorophyll content and $P \mathrm{n}$ were significantly decreased in $P$. massoniana under simulated AR treatment. Similar results were observed in AR-treated Arabidopsis and woody plants [10,14,17]. On the contrary, no significant changes in the chlorophyll content and Pn were found in $T$. wallichiana var. mairei (Figure 1B,C) under simulated AR, indicating that T. wallichiana var. mairei is more resistant than $P$. massoniana in response to AR stress.

Figure 1. Morphological and physiological changes of $P$. massoniana and T. wallichinana var. mairei under distilled water as control (CK) and simulated acid rain (AR) stress. (A) Injury phenotype; (B) total chlorophyll content; $(\mathbf{C})$ photosynthesis $(P \mathrm{n})$. Data are means $\pm \mathrm{SE}$ from measurements of five replicate experiments.

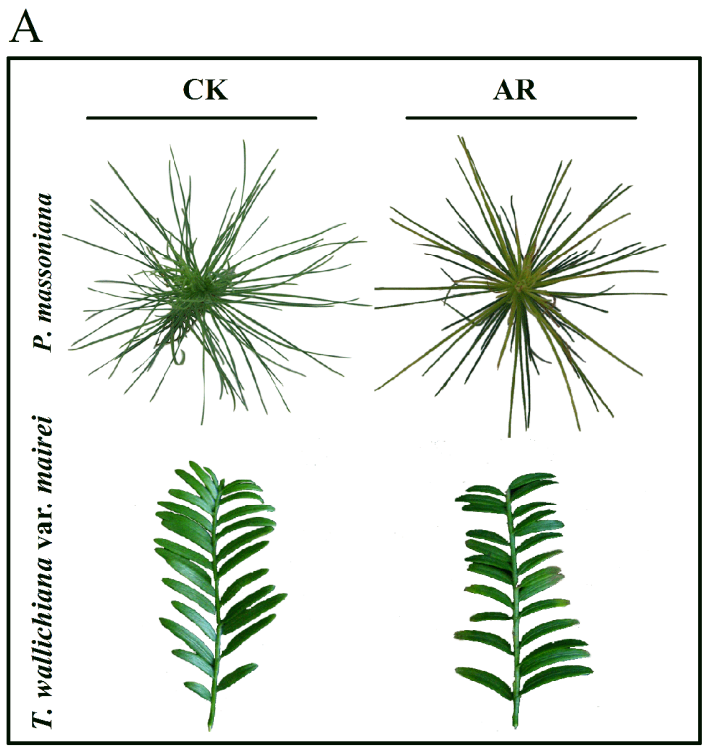

$\mathrm{B}$

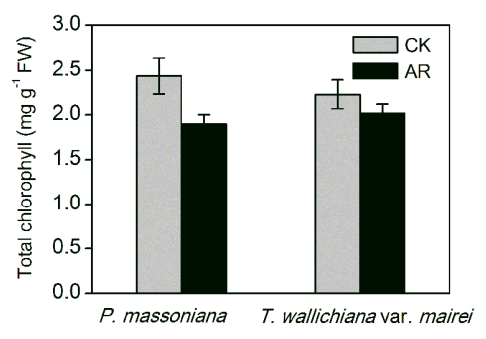

$\mathrm{C}$

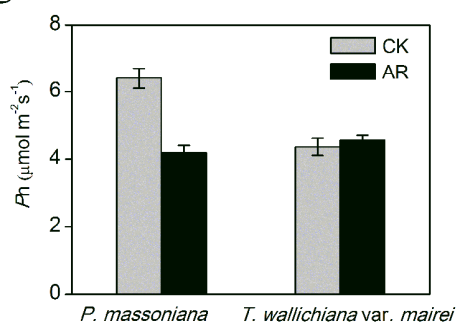


2.1.2. Identification and Functional Classification of AR-Responsive Proteins in P. massoniana and T. wallichiana var. mairei

To further explore the proteome changes in P. massoniana and T. wallichiana var. mairei leaves under AR treatment, 2-DE was performed in this study. A total of 73 protein spots from P. massoniana gels and 31 protein spots from $T$. wallichiana var. maire gels showed significant changes. Tables S1 and S2 showed the details of identified proteins. Out of these spots, a total of 65 and 26 proteins were identified by mass spectrometry in P. massoniana and T. wallichiana var. mairei, respectively. Those with expression abundance changed more than 2-fold among three different repetitions, were identified as the differentially expressed proteins after AR treatment (Figure 2). Close-up views of several protein spots are shown in Figure 2B,D.

Figure 2. 2-DE image analysis of proteins extracted from $P$. massoniana and T. wallichinana var. mairei leaves. The numbers assigned to the proteins spots correspond to those listed in Tables 1 and 2. (A) A representative Coomassie Brilliant Blue (CBB) R250-stained 2D gel of total soluble proteins from P. massoniana. Arrows indicate 65 spots showing at least 2-fold changes $(p<0.05)$ were analyzed by Matrix-assisted laser desorption/ionization-time-of-flight mass spectrometry (MALDI-TOF MS); (B) Close-up view of some differentially expressed protein spots in P. massoniana; (C) A representative CBB R250-stained 2D gel of total soluble proteins from $T$. wallichinana var. mairei. Arrows indicate 26 spots showing at least 2-fold changes $(p<0.05)$ were analyzed by MALDI-TOF MS; (D) Close-up view of some differentially expressed protein spots in $T$. wallichinana var. mairei.
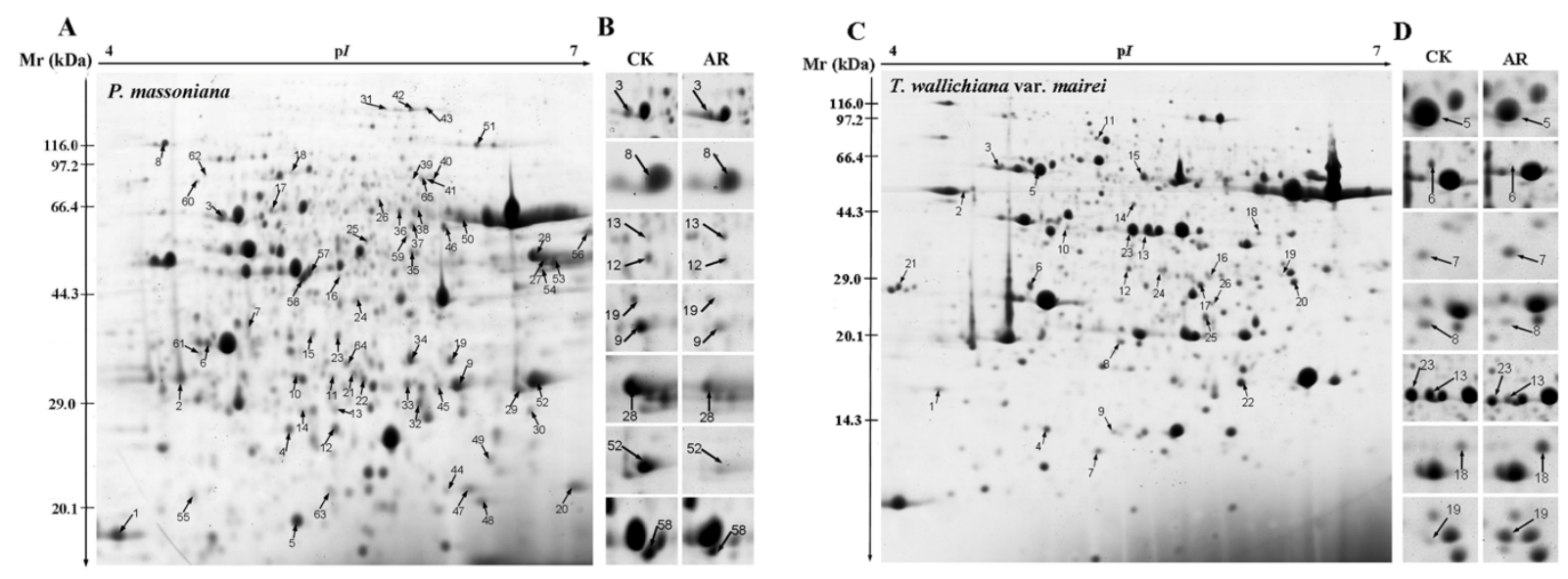
Table 1. Identification of differentially expressed proteins using 2-DE and mass spectrometry analysis in Pinus massoniana.

\begin{tabular}{|c|c|c|c|c|c|c|c|c|c|}
\hline Spot $^{a}$ & $\begin{array}{c}\text { NCBI } \\
\text { accession }^{b}\end{array}$ & Protein identity $^{c}$ & $\begin{array}{c}\text { Thero. } \\
\text { kDa/pI } I^{\text {d }}\end{array}$ & $\begin{array}{c}\text { Exper. } \\
\text { kDa/pI }{ }^{\mathrm{e}}\end{array}$ & $\mathrm{SC}^{\mathrm{f}}$ & $\mathbf{M P} / \mathbf{T P}^{\mathrm{g}}$ & Score $^{h}$ & $\mathrm{C}^{\mathrm{i}}$ & Species \\
\hline \multicolumn{10}{|c|}{ Metabolism } \\
\hline 4 & gi|308807529 & aminoimidazole ribonucleotide carboxylase & $62.31 / 6.2$ & $27.37 / 5.18$ & $17 \%$ & $9 / 14$ & 97 & $\mathrm{U}$ & Ostreococcus tauri \\
\hline 12 & gi|90718161 & granule bound starch synthase & $37.38 / 7.11$ & $27.42 / 5.44$ & $31 \%$ & $7 / 13$ & 91 & $\mathrm{D}$ & Ficus hispidioides \\
\hline 16 & gi|357122042 & UDP-arabinopyranose mutase 3-like & $41.34 / 6.02$ & $48.06 / 5.46$ & $25 \%$ & $9 / 12$ & 95 & $\mathrm{U}$ & Brachypodium distachyon \\
\hline 24 & gi|224122152 & mitochondrial phosphate carrier protein & $38.64 / 9.18$ & $44.04 / 5.56$ & $21 \%$ & $8 / 13$ & 103 & $\mathrm{D}$ & Populus trichocarpa \\
\hline 27 & gi|435103 & glyceraldehyde-phosphate dehydrogenase & $44.66 / 7.55$ & $51.45 / 6.65$ & $32 \%$ & $10 / 12$ & 145 & $\mathrm{D}$ & Pinus sylvestris \\
\hline 28 & gi|396547 & glutamate-ammonia ligase & $39.79 / 6.42$ & $52.00 / 6.55$ & $20 \%$ & $18 / 23$ & 86 & $\mathrm{D}$ & Pinus sylvestris \\
\hline 29 & gi|308806413 & putative D-protein & $22.80 / 6.74$ & $31.71 / 6.42$ & $32 \%$ & $7 / 9$ & 98 & $\mathrm{D}$ & Ostreococcus tauri \\
\hline 34 & gi|357448955 & nicotianamine synthase & $32.03 / 8.11$ & $35.56 / 5.88$ & $25 \%$ & $6 / 6$ & 105 & $\mathrm{D}$ & Medicago truncatula \\
\hline 39 & gi|303281782 & $\mathrm{ABC}$ transporter & $130.84 / 6.55$ & $85.07 / 5.89$ & $10 \%$ & $9 / 11$ & 92 & $\mathrm{D}$ & Micromonas pusilla \\
\hline 41 & gi|13873338 & lipoic acid synthase & $41.75 / 8.61$ & $84.86 / 5.95$ & $23 \%$ & $6 / 7$ & 91 & $\mathrm{D}$ & Bruguiera gymnorhiza \\
\hline 48 & gi|190899164 & $2 \mathrm{Fe}-2 \mathrm{~S}$ ferredoxin & $18.33 / 8.52$ & $20.94 / 6.21$ & $38 \%$ & $4 / 4$ & 81 & $\mathrm{D}$ & Populus tremula \\
\hline 54 & gi|15240625 & transaldolase & $47.96 / 6.08$ & $49.44 / 6.61$ & $13 \%$ & $6 / 6$ & 92 & $\mathrm{D}$ & Arabidopsis thaliana \\
\hline 57 & gi|126583387 & ferritin & $28.26 / 5.66$ & $49.03 / 5.29$ & $24 \%$ & $4 / 4$ & 75 & $\mathrm{D}$ & Triticum urartu \\
\hline \multicolumn{10}{|c|}{ Cell structure } \\
\hline 62 & gi|29028306 & UDP-glucose dehydrogenase & $53.52 / 6.06$ & $87.31 / 4.70$ & $21 \%$ & $7 / 8$ & 101 & $\mathrm{D}$ & Colocasia esculenta \\
\hline
\end{tabular}


Table 1. Cont.

\begin{tabular}{|c|c|c|c|c|c|c|c|c|c|}
\hline Spot $^{a}$ & $\begin{array}{c}\text { NCBI } \\
\text { accession }^{b}\end{array}$ & Protein identity $^{c}$ & $\begin{array}{l}\text { Thero. } \\
\text { kDa/pI } I^{\text {d }}\end{array}$ & $\begin{array}{l}\text { Exper. } \\
\mathrm{kDa} / \mathbf{p} I^{\mathrm{e}}\end{array}$ & $\mathrm{SC}^{\mathrm{f}}$ & $\mathbf{M P} / \mathbf{T P}^{\mathrm{g}}$ & Score $^{h}$ & $\mathbf{C}^{\mathrm{i}}$ & Species \\
\hline \multicolumn{10}{|c|}{ Protein synthesis and modification } \\
\hline 6 & gi|357111489 & oxygen-evolving enhancer protein 1 & $24.81 / 4.97$ & $37.64 / 4.72$ & $26 \%$ & $6 / 10$ & 91 & $\mathrm{U}$ & Brachypodium distachyon \\
\hline 11 & gi| 46811008 & small ribosomal protein 4 & $22.28 / 10.24$ & $33.33 / 5.43$ & $38 \%$ & $6 / 9$ & 87 & $\mathrm{U}$ & Haplomitrium blumei \\
\hline 20 & gi|308801835 & Ulp1 protease family protein & $68.17 / 9.21$ & $22.11 / 6.90$ & $22 \%$ & $12 / 15$ & 117 & $\mathrm{D}$ & Ostreococcus tauri \\
\hline 21 & gi|297830742 & kinase family protein & $43.77 / 5.79$ & $33.72 / 5.55$ & $31 \%$ & $7 / 10$ & 97 & $\mathrm{D}$ & Arabidopsis lyrata subsp \\
\hline 31 & gi 6525065 & chloroplast translational elongation factor $\mathrm{Tu}$ & $50.55 / 6.05$ & $139.96 / 5.73$ & $27 \%$ & $9 / 11$ & 109 & $\mathrm{D}$ & Oryza sativa Japonica Group \\
\hline 37 & gi|159477317 & T-complex protein 1 beta subunit & $57.40 / 5.37$ & $58.03 / 5.88$ & $30 \%$ & $14 / 18$ & 152 & $\mathrm{U}$ & Chlamydomonas reinhardtii \\
\hline 45 & gi|233142272 & glycogen synthase kinase & $47.06 / 8.64$ & $31.97 / 6.00$ & $25 \%$ & $8 / 12$ & 100 & $\mathrm{D}$ & Glycine $\max$ \\
\hline 49 & gi| 255560267 & chaperonin-60kD & $61.48 / 6.20$ & $24.54 / 6.25$ & $14 \%$ & $6 / 7$ & 76 & $\mathrm{D}$ & Ricinus communis \\
\hline \multicolumn{10}{|c|}{ Photosynthesis and energy production } \\
\hline 3 & gi|228016009 & ATP synthase CF1 beta subunit & $52.92 / 5.19$ & $60.32 / 4.79$ & $43 \%$ & $18 / 30$ & 161 & $\mathrm{U}$ & Pinus resinosa \\
\hline 9 & gi|357481701 & Ycf2 & $108.70 / 8.98$ & $32.16 / 6.10$ & $13 \%$ & $8 / 10$ & 88 & $\mathrm{D}$ & Medicago truncatula \\
\hline 17 & gi|56784992 & putative ATP synthase beta subunit & $45.27 / 5.26$ & $64.05 / 5.08$ & $47 \%$ & $13 / 19$ & 167 & $\mathrm{U}$ & Oryza sativa Japonica Group \\
\hline 18 & gi|220938463 & $\begin{array}{l}\text { phosphoenolpyruvate carboxykinase (PEP } \\
\text { carboxykinase) }\end{array}$ & $55.85 / 6.63$ & $89.72 / 5.19$ & $19 \%$ & $7 / 9$ & 95 & $\mathrm{D}$ & Hyparrhenia hirta \\
\hline 35 & gi| 18073888 & phosphoenolpyruvate carboxylase(PPCK) & $41.34 / 7.74$ & $52.73 / 5.88$ & $24 \%$ & $6 / 7$ & 94 & $\mathrm{D}$ & Leptotes bicolor \\
\hline 44 & gi|31281466 & $\begin{array}{l}\text { ribulose-1,5-bisphosphate carboxylase/oxygenase } \\
\text { large subunit(Rubisco) }\end{array}$ & $52.11 / 6.09$ & $21.97 / 6.05$ & $16 \%$ & $8 / 14$ & 88 & $\mathrm{D}$ & Pinus monophylla \\
\hline 50 & gi|166714465 & $\begin{array}{l}\text { ribulose-1,5-bisphosphate carboxylase/oxygenase } \\
\text { large subunit(Rubisco) }\end{array}$ & $51.60 / 6.00$ & $59.41 / 6.11$ & $36 \%$ & $21 / 27$ & 223 & $\mathrm{D}$ & Pinus parviflora \\
\hline 53 & gi|332591479 & phosphoglycerate kinase 1 & $52.94 / 8.84$ & $50.50 / 6.73$ & $36 \%$ & $15 / 22$ & 153 & $\mathrm{D}$ & Pinus pinaster \\
\hline 55 & gi|34733684 & $\begin{array}{l}\text { ribulose-1,5-bisphosphate carboxylase/oxygenase } \\
\text { large subunit(Rubisco) }\end{array}$ & $48.97 / 6.34$ & $21.49 / 4.63$ & $14 \%$ & $6 / 6$ & 90 & $\mathrm{D}$ & Gnetum hainanense \\
\hline 60 & gi|264160443 & ribulose 1,5-bisphosphate carboxylase & $46.11 / 6.08$ & $82.57 / 4.66$ & $14 \%$ & $8 / 11$ & 87 & $\mathrm{D}$ & Callistephus chinensis \\
\hline 65 & gi|357111628 & $\begin{array}{l}\text { succinate dehydrogenase [ubiquinone] } \\
\text { flavoprotein subunit }\end{array}$ & $68.79 / 6.18$ & $84.59 / 5.93$ & $14 \%$ & $7 / 8$ & 90 & $\mathrm{U}$ & Brachypodium distachyon \\
\hline
\end{tabular}


Table 1. Cont

\begin{tabular}{|c|c|c|c|c|c|c|c|c|c|}
\hline Spot $^{a}$ & $\begin{array}{c}\text { NCBI } \\
\operatorname{accession}^{b}\end{array}$ & Protein identity $^{c}$ & $\begin{array}{c}\text { Thero. } \\
\text { kDa/pI }{ }^{\text {d }}\end{array}$ & $\begin{array}{c}\text { Exper. } \\
\text { kDa/p } I^{\mathrm{e}}\end{array}$ & $\mathrm{SC}^{\mathrm{f}}$ & $\mathbf{M P} / \mathbf{T P}^{\mathrm{g}}$ & Score $^{h}$ & $\mathbf{C}^{\mathrm{i}}$ & Species \\
\hline \multicolumn{10}{|c|}{ Stress and defense } \\
\hline 5 & gi $\mid 255575353$ & peroxiredoxin & $23.94 / 7.63$ & $19.53 / 5.23$ & $22 \%$ & $5 / 6$ & 83 & $\mathrm{D}$ & Ricinus communis \\
\hline 10 & gi|192912966 & cytosolic ascorbate peroxidase & $27.550 / 5.42$ & $33.28 / 5.22$ & $38 \%$ & $7 / 9$ & 98 & $\mathrm{U}$ & Elaeis guineensis \\
\hline 13 & gi|289187423 & tau class glutathione $\mathrm{S}$-transferase & $26.47 / 5.56$ & $29.44 / 5.44$ & $36 \%$ & $11 / 22$ & 95 & $\mathrm{U}$ & Pinus brutia \\
\hline 14 & gi|289187423 & tau class glutathione S-transferase & $26.47 / 5.56$ & $29.21 / 5.25$ & $35 \%$ & $10 / 14$ & 103 & $\mathrm{U}$ & Pinus brutia \\
\hline 30 & gi|66841104 & manganese superoxide dismutase & $13.31 / 5.85$ & $29.40 / 6.52$ & $46 \%$ & $5 / 6$ & 97 & $\mathrm{D}$ & Larix gmelinii \\
\hline 33 & gi|154101561 & phenylalanine ammonia-lyase & $24.86 / 6.54$ & $32.30 / 5.86$ & $27 \%$ & $5 / 7$ & 84 & $\mathrm{D}$ & Scutellaria baicalensis \\
\hline 36 & gi|380863088 & stromal ascorbate peroxidase & $80.54 / 9.10$ & $63.15 / 5.81$ & $57 \%$ & $4 / 4$ & 92 & $\mathrm{D}$ & Dimocarpus longan \\
\hline 43 & gi|357513733 & Tir-nbs-lrr resistance protein & $140.72 / 5.31$ & $140.40 / 5.95$ & $12 \%$ & $12 / 15$ & 110 & $\mathrm{D}$ & Medicago truncatula \\
\hline 51 & gi|195620494 & membrane-associated salt-inducible protein & $43.66 / 9.02$ & $114.61 / 6.19$ & $20 \%$ & $7 / 9$ & 102 & $\mathrm{U}$ & Zea mays \\
\hline 59 & gi|308804281 & cytochrome b5 & $16.34 / 7.90$ & $55.92 / 5.86$ & $45 \%$ & $5 / 6$ & 92 & $\mathrm{D}$ & Ostreococcus tauri \\
\hline 64 & gi|56481813 & thiazole biosynthetic enzyme & $36.63 / 6.01$ & $35.00 / 5.51$ & $29 \%$ & $8 / 11$ & 85 & $\mathrm{D}$ & Pseudotsuga menziesii \\
\hline \multicolumn{10}{|c|}{ Hormone response } \\
\hline 7 & gi $\mid 212725010$ & abscisic acid and water-stress induced protein & $16.30 / 9.55$ & $40.39 / 4.95$ & $28 \%$ & $4 / 5$ & 81 & $\mathrm{U}$ & Pinus sylvestris \\
\hline 40 & gi|224108798 & gibberellin 2-oxidase & $34.47 / 5.44$ & $84.30 / 5.98$ & $29 \%$ & $8 / 10$ & 106 & $\mathrm{D}$ & Populus trichocarpa \\
\hline 47 & gi|357485291 & auxin-responsive protein & $36.69 / 8.52$ & $21.95 / 6.15$ & $18 \%$ & $6 / 6$ & 80 & $\mathrm{D}$ & Medicago truncatula \\
\hline \multicolumn{10}{|c|}{ Signal transduction } \\
\hline 8 & gi|145336050 & caleosin-related protein & $23.89 / 9.62$ & $116.00 / 4.47$ & $40 \%$ & $6 / 7$ & 97 & $\mathrm{D}$ & Arabidopsis thaliana \\
\hline 25 & gi|22128710 & putative signal tranduction protein & $97.72 / 6.16$ & $54.98 / 5.62$ & $13 \%$ & $9 / 11$ & 101 & $\mathrm{D}$ & Oryza sativa Japonica Group \\
\hline 42 & gi|226494574 & $\mathrm{T}$-cell activation protein phosphatase $2 \mathrm{C}$-like protein & $34.59 / 7.70$ & $140.00 / 5.88$ & $22 \%$ & $5 / 5$ & 84 & $\mathrm{D}$ & Zea mays \\
\hline 52 & gi|225425656 & probable calcium-binding protein CML30 & $20.64 / 4.66$ & $32.35 / 6.55$ & $30 \%$ & $5 / 5$ & 97 & $\mathrm{D}$ & Vitis vinifera \\
\hline 63 & gi|357440111 & calcium-dependent protein kinase & $54.85 / 5.85$ & $21.74 / 5.42$ & $17 \%$ & $7 / 8$ & 84 & $\mathrm{D}$ & Medicago truncatula \\
\hline
\end{tabular}


Table 1. Cont

\begin{tabular}{|c|c|c|c|c|c|c|c|c|c|}
\hline Spot $^{a}$ & $\begin{array}{c}\text { NCBI } \\
\text { accession }^{b}\end{array}$ & Protein identity $^{c}$ & $\begin{array}{c}\text { Thero. } \\
\text { kDa/pI } I^{\text {d }}\end{array}$ & $\begin{array}{c}\text { Exper. } \\
\text { kDa/pI }\end{array}$ & $S C C^{f}$ & $\mathbf{M P} / \mathbf{T P}^{\mathrm{g}}$ & Score $^{h}$ & $\mathrm{C}^{\mathrm{i}}$ & Species \\
\hline \multicolumn{10}{|c|}{ Transcription } \\
\hline 15 & gi|384584973 & maturase $\mathrm{K}$ & $31.08 / 10.17$ & $38.94 / 5.31$ & $30 \%$ & $6 / 8$ & 100 & $\mathrm{D}$ & Cynodon nlemfuensis \\
\hline 22 & gi|313199657 & RNA polymerase beta subunit & $120.90 / 6.41$ & $32.90 / 5.60$ & $9 \%$ & $8 / 9$ & 78 & $\mathrm{D}$ & Isoetes flaccida \\
\hline 23 & gi|372482380 & RNA polymerase beta subunit & $158.24 / 9.38$ & $38.65 / 5.46$ & $11 \%$ & $14 / 20$ & 109 & $\mathrm{D}$ & Sansevieria trifasciata \\
\hline 26 & gi|18419497 & transposase & $15.77 / 8.93$ & $69.37 / 5.69$ & $44 \%$ & $5 / 6$ & 89 & $\mathrm{D}$ & Oryza nivara \\
\hline 56 & gi| 108862655 & retrotransposon protein & $21.22 / 8.62$ & $56.71 / 6.93$ & $32 \%$ & $6 / 8$ & 93 & $\mathrm{D}$ & Oryza sativa Japonica Group \\
\hline \multicolumn{10}{|c|}{ Function unknown and hypothetical proteins } \\
\hline 1 & gi|326501884 & predicted protein & $53.01 / 5.32$ & $18.56 / 4.20$ & $18 \%$ & $7 / 11$ & 84 & $\mathrm{D}$ & Hordeum vulgare subsp \\
\hline 2 & gi|21593511 & pheromone receptor & $39.28 / 4.44$ & $33.13 / 4.56$ & $24 \%$ & $5 / 6$ & 83 & $\mathrm{D}$ & Arabidopsis thaliana \\
\hline 19 & gi|118486611 & unknown & $43.94 / 6.43$ & $35.36 / 6.07$ & $19 \%$ & $6 / 9$ & 78 & $\mathrm{D}$ & Populus trichocarpa \\
\hline 32 & gi|116780007 & unknown & $25.59 / 5.82$ & $30.20 / 5.92$ & $45 \%$ & $13 / 29$ & 120 & $\mathrm{D}$ & Picea sitchensis \\
\hline 38 & gi|148906365 & unknown & $48.34 / 5.78$ & $63.66 / 5.90$ & $29 \%$ & $11 / 16$ & 109 & $\mathrm{U}$ & Picea sitchensis \\
\hline 46 & gi|116789937 & unknown & $54.01 / 6.00$ & $57.72 / 6.04$ & $23 \%$ & $12 / 17$ & 116 & $\mathrm{D}$ & Picea sitchensis \\
\hline 58 & gi|357488033 & hypothetical protein MTR_5g047930 & $54.35 / 4.92$ & $47.79 / 5.26$ & $19 \%$ & $6 / 9$ & 78 & $\mathrm{D}$ & Medicago truncatula \\
\hline 61 & gi|242033729 & hypothetical protein SORBIDRAFT_01g015060 & $18.87 / 4.75$ & $36.24 / 4.67$ & $32 \%$ & $5 / 6$ & 85 & $\mathrm{U}$ & Sorghum bicolor \\
\hline
\end{tabular}

${ }^{a}$ Spot. is the unique differentially expressed protein spot number; ${ }^{b}$ Database accession numbers according to NCBInr; ${ }^{c}$ The name of the proteins identified by MALDI-TOF MS;

${ }^{\mathrm{d}}$ Theoretical mass $(\mathrm{kDa})$ and $\mathrm{p} I$ of identified proteins; ${ }^{\mathrm{e}}$ Experimental mass (kDa) and $\mathrm{p} I$ of identified proteins; ${ }^{\mathrm{f}}$ The amino acid sequence coverage for the identified proteins; ${ }^{\mathrm{g}}$ Number of the matched peptides and the total searched peptides; ${ }^{\mathrm{h}}$ The Mascot searched score against the database NCBInr; ${ }^{\mathrm{i}}$ Spot abundance change. U stands for increased abundance of protein, D stands for decreased abundance of protein. 
Table 2. Identification of differentially expressed proteins using 2-DE and mass spectrometry analysis in Taxus wallichiana var.mairei.

\begin{tabular}{|c|c|c|c|c|c|c|c|c|c|}
\hline Spot $^{\mathrm{a}}$ & $\begin{array}{c}\text { NCBI } \\
\text { accession } \\
\end{array}$ & Protein identity ${ }^{c}$ & $\begin{array}{c}\text { Thero. } \\
\text { kDa/p } I^{\text {d }}\end{array}$ & $\begin{array}{c}\text { Exper. } \\
\mathrm{kDa} / \mathbf{p} I^{\mathrm{e}}\end{array}$ & $\mathbf{S C}^{\mathrm{f}}$ & $\mathbf{M P} / \mathbf{T P}^{\mathrm{g}}$ & Score $^{\mathrm{h}}$ & $\mathbf{C}^{\mathrm{i}}$ & Species \\
\hline \multicolumn{10}{|c|}{ Metabolism } \\
\hline 9 & gi|3913651 & ferredoxin-NADP reductase & $40.71 / 8.37$ & $11.75 / 5.40$ & $35 \%$ & $6 / 9$ & 88 & $\mathrm{U}$ & Nicotiana tabacum \\
\hline 13 & gi|15228869 & copper chaperone & $13.08 / 4.91$ & $39.62 / 5.55$ & $33 \%$ & $4 / 4$ & 87 & $\mathrm{D}$ & Arabidopsis thaliana \\
\hline 21 & gi|334184891 & aconitase/3-isopropylmalate dehydratase protein & $23.88 / 6.16$ & $28.02 / 4.47$ & $36 \%$ & $6 / 8$ & 96 & $\mathrm{U}$ & Arabidopsis thaliana \\
\hline \multicolumn{10}{|c|}{ Cell structure } \\
\hline 14 & gi|2500930 & beta-fructofuranosidase & $62.90 / 7.07$ & $46.39 / 5.49$ & $13 \%$ & $6 / 6$ & 94 & $\mathrm{U}$ & Pisum sativum \\
\hline 23 & gi|357521323 & microtubule associated protein type 2 & $70.55 / 9.05$ & $39.64 / 5.49$ & $20 \%$ & $9 / 12$ & 102 & $\mathrm{D}$ & Medicago truncatula \\
\hline 25 & gi|159490038 & eta tubulin & $35.80 / 7.75$ & $23.31 / 5.80$ & $29 \%$ & $6 / 8$ & 94 & $\mathrm{U}$ & Chlamydomonas reinhardtil \\
\hline \multicolumn{10}{|c|}{ Photosynthesis and energy production } \\
\hline 1 & gi|226498532 & NADH-ubiquinone oxidoreductase $10.5 \mathrm{kDa}$ subunit & $11.28 / 9.15$ & $15.08 / 4.64$ & $47 \%$ & $4 / 4$ & 85 & $\mathrm{U}$ & Zea mays \\
\hline 3 & gi|138277483 & ATP synthase beta subunit & $51.67 / 5.11$ & $63.61 / 4.90$ & $42 \%$ & $18 / 30$ & 170 & $\mathrm{D}$ & Taxus brevifolia \\
\hline 5 & gi|138277483 & ATP synthase beta subunit & $51.67 / 5.11$ & $62.00 / 5.08$ & $45 \%$ & $20 / 37$ & 167 & $\mathrm{D}$ & Taxus brevifolia \\
\hline 10 & gi|357137138 & phosphoribulokinase & $45.31 / 5.97$ & $40.14 / 5.21$ & $27 \%$ & $7 / 11$ & 95 & $\mathrm{U}$ & Brachypodium distachyon \\
\hline 11 & gi|225459844 & ATP-dependent zinc metalloprotease FTSH & $75.76 / 6.36$ & $84.83 / 5.33$ & $27 \%$ & $15 / 28$ & 124 & $\mathrm{U}$ & Vitis vinifera \\
\hline 12 & gi|7592732 & plasma membrane $\mathrm{H}^{+}$-ATPase & $22.04 / 8.92$ & $31.30 / 5.47$ & $38 \%$ & $6 / 6$ & 102 & $\mathrm{U}$ & Nepenthes alata \\
\hline 15 & gi|150251443 & ATP synthase CF1 alpha chain & $55.36 / 5.38$ & $57.82 / 5.53$ & $15 \%$ & $9 / 12$ & 99 & $\mathrm{D}$ & Cycas taitungensis \\
\hline 16 & gi|154146830 & phosphoenolpyruvate carboxylase & $49.31 / 6.21$ & $29.94 / 5.82$ & $29 \%$ & $8 / 10$ & 118 & $\mathrm{U}$ & Cymbopogon citratus \\
\hline 20 & gi|350536787 & chloroplast malate dehydrogenase & $47.79 / 5.92$ & $28.80 / 6.19$ & $23 \%$ & $8 / 8$ & 110 & $\mathrm{U}$ & Solanum lycopersicum \\
\hline \multicolumn{10}{|c|}{ Stress and defense } \\
\hline 6 & gi|357520455 & cysteine proteinase inhibitor & $25.78 / 7.78$ & $28.19 / 5.04$ & $21 \%$ & $6 / 6$ & 84 & $\mathrm{D}$ & Medicago truncatula \\
\hline \multicolumn{10}{|c|}{ Hormone response } \\
\hline 4 & gi|76009223 & isochorismate synthase & $13.34 / 8.47$ & $11.83 / 5.11$ & $32 \%$ & $4 / 4$ & 82 & $\mathrm{U}$ & Solanum lycopersicum \\
\hline 19 & gi|335346406 & abscisic acid 8-hydroxylase & $53.18 / 8.77$ & $30.53 / 6.17$ & $17 \%$ & $7 / 9$ & 88 & $\mathrm{D}$ & Ipomoea nil \\
\hline
\end{tabular}


Table 2. Cont.

\begin{tabular}{|c|c|c|c|c|c|c|c|c|c|}
\hline Spot $^{a}$ & $\begin{array}{c}\text { NCBI } \\
\operatorname{accession}^{b}\end{array}$ & Protein identity $^{c}$ & $\begin{array}{c}\text { Thero. } \\
\text { kDa/p } I^{\text {d }}\end{array}$ & $\begin{array}{c}\text { Exper. } \\
\text { kDa/p } I^{\mathrm{e}}\end{array}$ & $\mathbf{S C}^{\mathbf{f}}$ & $\mathbf{M P} / \mathbf{T P}^{\mathrm{g}}$ & Score $^{h}$ & $\mathbf{C}^{\mathrm{i}}$ & Species \\
\hline \multicolumn{10}{|c|}{ Signal transduction } \\
\hline 2 & gi|357132195 & $\begin{array}{l}\text { light-mediated development protein DET1-like } \\
\text { isoform } 2\end{array}$ & $48.61 / 8.53$ & $49.88 / 4.76$ & $17 \%$ & $7 / 9$ & 95 & $\mathrm{U}$ & Brachypodium distachyon \\
\hline 8 & gi|384245525 & calcium-binding protein CML19 (centrin) & $19.59 / 4.75$ & $19.99 / 5.44$ & $31 \%$ & $4 / 4$ & 78 & $\mathrm{D}$ & Coccomyxa subellipsoidea \\
\hline 17 & gi| 356573251 & calcium-binding protein KIC-like & $14.00 / 4.18$ & $28.30 / 5.78$ & $47 \%$ & $5 / 5$ & 85 & $\mathrm{D}$ & Glycine max \\
\hline \multicolumn{10}{|c|}{ Transcription } \\
\hline 7 & gi| $\mid 154082680$ & maturase $\mathrm{K}$ & $57.14 / 9.40$ & $10.70 / 5.33$ & $12 \%$ & $6 / 6$ & 85 & $\mathrm{U}$ & Haplophyllum buxbaumii \\
\hline 24 & gi|79481163 & $\begin{array}{l}\text { RNA polymerase II } C \text {-terminal domain } \\
\text { phosphatase-like } 1\end{array}$ & $109.15 / 5.81$ & $30.99 / 5.62$ & $15 \%$ & $10 / 13$ & 103 & $\mathrm{U}$ & Arabidopsis thaliana \\
\hline 26 & gi|15341050 & maturase $\mathrm{K}$ & $33.04 / 9.65$ & $25.36 / 5.83$ & $31 \%$ & $7 / 11$ & 99 & $\mathrm{U}$ & Persicaria runcinata \\
\hline \multicolumn{10}{|c|}{ Function unknown and hypothetical proteins } \\
\hline 18 & gi|125547814 & hypothetical protein OsI_15422 & $45.62 / 6.20$ & $38.91 / 6.03$ & $22 \%$ & $7 / 10$ & 94 & $\mathrm{U}$ & Oryza sativa Indica Group \\
\hline 22 & gi|296087931 & unnamed protein product & $79.30 / 7.32$ & $15.63 / 5.96$ & $20 \%$ & $11 / 16$ & 106 & $\mathrm{D}$ & Vitis vinifera \\
\hline
\end{tabular}

${ }^{a}$ Spot. is the unique differentially expressed protein spot number; ${ }^{b}$ Database accession numbers according to NCBInr; ${ }^{c}$ The name of the proteins identified by MALDI-TOF MS; ${ }^{\mathrm{d}}$ Theoretical mass (kDa) and $\mathrm{p} I$ of identified proteins; ${ }^{\mathrm{e}}$ Experimental mass (kDa) and $\mathrm{p} I$ of identified proteins; ${ }^{\mathrm{f}}$ The amino acid sequence coverage for the identified proteins; ${ }^{\mathrm{g}}$ Number of the matched peptides and the total searched peptides; ${ }^{\mathrm{h}}$ The Mascot searched score against the database NCBInr; ${ }^{\mathrm{i}}$ Spot abundance change. U stands for increased abundance of protein, D stands for decreased abundance of protein. 
The identified proteins were divided into seven groups based on their biological functions in both P. massoniana and T. wallichiana var. mairei (Figure 3A,B). In P. massoniana, the largest group was metabolism $(20 \%)$, the following groups were photosynthesis and energy production (16.9\%), stress and defense (16.9\%), protein synthesis and modification (12.3\%), signal transduction (7.7\%), transcription (7.7\%), hormone response $(4.7 \%)$, cell structure $(1.5 \%)$, and function unknown and hypothetical proteins (12.3\%) (Figure 3A). In T. wallichiana var. mairei, the identified proteins were involved in photosynthesis and energy production $(34.7 \%)$, metabolism $(11.5 \%)$, cell structure (11.5\%), signal transduction (11.5\%), transcription (11.5\%), stress and defense $(3.9 \%)$, hormone response (7.7\%), and function unknown and hypothetical proteins (7.7\%) (Figure 3B). This result suggests that proteins involved in metabolism, cell structure, protein synthesis-related proteins, stress response, signal transduction and transcription play an important role in AR tolerance.

Figure 3. Functional category distribution of the identified proteins in P. massoniana and T. wallichinana var. mairei under the AR treatment. Each identified protein listed in Tables 1 and 2 was functionally classified based on their known and putative functions. The pie chart indicates the percentage of the AR-responsive proteins identified in each functional category. (A) AR-responsive proteins in P. massoniana; (B) AR-responsive proteins in T. wallichinana var. mairei; (C) Number of protein spots significantly up-regulated and down-regulated in P. massoniana and T. wallichinana var. mairei under AR stress.

A

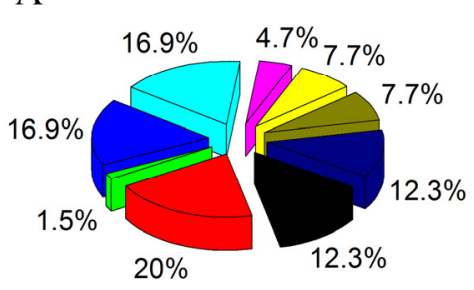

Metabolism

Metabolism

Protein synthesis and modification

Photosynthesis and energy production

Stress and defense

Hormone response

Signal transduction

Transcription

Function unknown and hypothetical proteins
B $\quad$ C
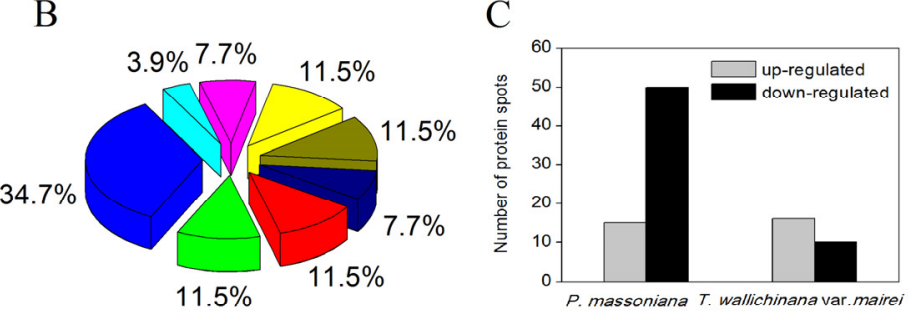

As shown in Figure 3C, the number of differentially expressed protein spots was more than double in P. massoniana compared to those in T. wallichiana var. mairei under AR stress. In AR-treated P. massoniana, 15 proteins were increased and 50 proteins were decreased (Figure 3C). Interestingly, 16 proteins were increased and only 10 proteins were decreased in AR-treated $T$. wallichiana var. mairei (Figure 3C). Most members of protein families were expressed in cytoplasm, chloroplasts, mitochondria and plasma membrane (Figure 4). After AR treatment, some proteins in T. wallichiana var. mairei were found to exhibit different expression patterns compared to P. massoniana, suggesting that tolerant plants can equip themselves better to respond to AR stress by provoking related proteins expression. 
Figure 4. Putative subcellular location model of AR stress response in P. massoniana and T. wallichinana var. mairei. The proteins marked in blue or orange represents they were found in P. massoniana or T. wallichinana var. mairei, respectively. Some of the AR-responsive proteins are indicated with those up-regulated marked by $\uparrow$ and those down-regulated marked by $\downarrow$. The abbreviations used in the Figure were explained in Tables 1 and 2.

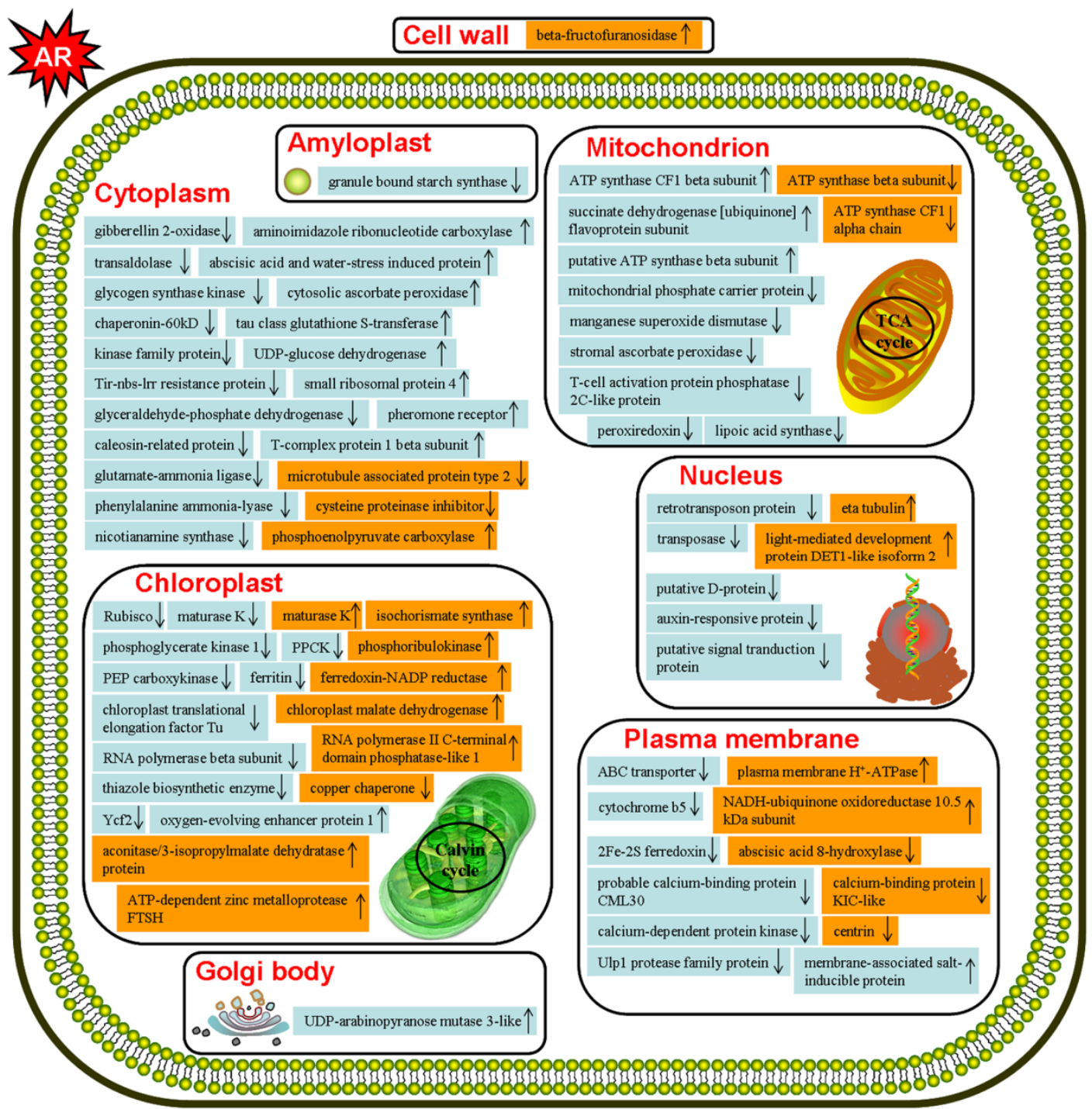

\subsection{Discussion}

\subsubsection{Metabolism Related Proteins}

Environmental stresses severely affect the metabolism of plants [15]. Thirteen metabolism-related proteins were exclusively affected by AR stress, with eleven down-regulated and two up-regulated in P. massoniana (Table 1) in our study. As observed in T. wallichiana var. mairei, only four up-regulated and two down-regulated proteins involved in metabolism were identified with altered abundance at least two-fold in response to AR treatment (Table 2). Nitrogen is an essential building block of nucleic acids and proteins, and nitrate assimilation greatly contributes to plant primary productivity [18]. Previous studies showed that salinity and water deficit strongly affected nitrogen metabolism and uptake of nitrate in wheat and rice $[19,20]$. In our study, glutamate-ammonia ligase, 
a key enzyme for nitrogen metabolism, belonging to the glutamine synthetase family was identified [18]. Kong et al. reported that low $\mathrm{pH}$ could potentially decrease the efficiency of nitrogen availability in P. massoniana [8]. Consistent with previous results, the abundance of glutamate-ammonia ligase (spot 28, Table 1) was decreased in P. massoniana under AR stress indicating that AR affected the primary metabolism of nitrogen in P. massoniana, whereas no nitrogen metabolism-related proteins have been identified in T. wallichiana var. mairei.

Donation of electrons by ferredoxin $(\mathrm{Fd})$ has been demonstrated in many other plastid enzymes, which is essential for multiple cellular processes, including nitrogen and sulfur assimilation, amino acid and fatty acid synthesis $[21,22]$. In this study, the abundance of $2 \mathrm{Fe}-2 \mathrm{~S}$ ferredoxin (spot 48 , Table 1) was decreased in AR-treated P. massoniana, indicating that nitrogen metabolism again, as well as sulfur metabolism, may be affected by AR treatment. Ferredoxin (flavodoxin)-NADP(H) reductases (FNRs) are ubiquitous flavoenzymes that deliver NADPH or low potential one-electron donors (ferredoxin) to redox-based metabolisms in plastids and mitochondria [23]. It is noteworthy that the overexpression of FNR can increase tolerance to oxidative stress in transgenic tobacco plants [24]. The up-regulation of FNR (spot 9, Table 2) in response to AR stress in T. wallichiana var. mairei reflects the role of this protein in basal metabolism under stress conditions. ABC transporters constitute one of the largest protein families with diverse functions in membrane transport [25]. Compared with control treatment, the abundance of $\mathrm{ABC}$ transporter (spot 39, Table 1) was decreased in P. massoniana under AR treatment. Earlier studies have detected a decrease in ABC transporter substrate binding protein in response to copper stress in Cannabis sativa roots, suggesting that the $\mathrm{ABC}$ transporter may play a very important role in the tolerance response of plant to environmental stresses [26]. Furthermore, the importance of $\mathrm{ABC}$ transporters has been reported for the integration of mitochondria in plant cellular iron homeostasis [25]. In plants, ferritin is an essential regulator of iron homeostasis, and the gene expression of ferritin is modulated by many environmental factors including drought and cold [27]. In our study, the abundance of ferritin (spot 57, Table 1) was decreased in P. massoniana under AR stress. The down-regulation of the protein related to transmembrane transport of molecules (e.g., the $\mathrm{ABC}$ transporter) and down-regulation of metal ion related proteins, is propitious for re-establishing cellular homeostasis in AR-treated P. massoniana. Based on the above results, we speculate that AR stress might affect more metabolic processes in P. massoniana than those in T. wallichiana var. mairei.

\subsubsection{Cell Structure Related Proteins}

The cytoskeleton is rapidly remodeled by various endogenous and external stimuli. We found that microtubule associated protein type 2 (spot 23, Table 2) decreased in abundance following AR treatment, while eta tubulin (spot 25, Table 2) was increased in T. wallichiana var. mairei under AR stress. Previous studies reported that the transverse orientation of cortical microtubule arrays in tobacco BY-2 cells was remodelled to a more random arrangement and the tubulin a-6 chain was induced in Arabidopsis roots after $\mathrm{NaCl}$ treatment [28]. Our results support that the accumulation of microtubule associated protein, rather than eta tubulin, could play a crucial role in the resistance to AR stress in T. wallichiana var. mairei. These universal cytoskeletal proteins may call into question their stronger tolerance in T. wallichiana var. mairei in response to AR than that in P. massoniana. Cell wall proteins are essential constituents of the plant cell wall, which are involved in modifications of 
cell wall components and structure, and signaling and interactions with plasma membrane proteins. Beta-fructofuranosidase is an enzyme involved in cell wall biosynthesis. In this study, the abundance of beta-fructofuranosidase (spot 14, Table 2) was increased in T. wallichiana var. mairei under AR treatment, indicating the stronger capacity of $T$. wallichiana var. mairei to recover from AR stress. In addition, UDP-glucose dehydrogenase, which is involved in cell wall pectin metabolic process, greatly contributes to AR-induced cell wall rigidification and physical barrier formation. The abundance of UDP-glucose dehydrogenase (spot 62, Table 1) was down-regulated in P. massoniana under AR treatment, which may result in perturbation of cell wall structure and more seriously damaged phenotypes in AR-treated P. massoniana.

\subsubsection{Protein Synthesis and Modification Related Proteins}

It is not surprising that AR stress also damaged the homeostasis of protein metabolism between biosynthesis and degradation. Singh et al. found that chloroplast translation elongation factor (EF-Tu) could play an important role in plant adaptation to environmental stresses in addition to its role in peptide elongation [29]. Indeed, our results provided additional evidence that a chloroplast translational elongation factor $\mathrm{Tu}$ (spot 31, Table 1) was down-regulated in P. massoniana after AR treatment, indicating that protein synthesizing machinery plays an important role in AR adaptation in this plant. Glycogen synthase kinase 3 (GSK-3) was originally identified as a regulator of glycogen synthesis in mammals. In plants, GSKs are reported to be involved in diverse important processes including hormone signaling, development, pathogenic stimuli and stress responses [30]. In this study, a glycogen synthase kinase (spot 45, Table 1) was down-regulated in P. massoniana under AR treatment. Indeed, our result provides extra evidence that GSKs play an important regulatory function under AR stress. Moreover, it is known that chaperonin is down-regulated under oxidative stress in rice [31]. Consistent with previous results, the decreased abundance of chaperonin-60kD (spot 49, Table 1) was observed in AR-treated P. massoniana. This finding suggests that chaperonin may be a general AR stress response element in P. massoniana. As a whole, these results suggest that AR treatment affected the biosynthesis and refolding of proteins and led to protein degradation, which is more pronounced in P. massoniana than in T. wallichiana var. mairei.

\subsubsection{Photosynthesis and Energy Production Related Proteins}

Photosynthesis is a key plant process affected by many environmental stresses. Physiological analysis showed the attenuation of photosynthesis in AR-stressed P. massoniana leaves, and similar patterns were also observed for most photosynthesis-related proteins (ribulose-1,5-bisphosphate carboxylase/oxygenase large subunit (Rubisco) (spots 44, 50, 55 and 60, Table 1), phosphoglycerate kinase (spot 53, Table 1)), whose abundances were deceased in AR-treated P. massoniana. Ohta et al. found that Rubisco was decreased in Synechocystis sp. PCC 6803 under acid condition [32]. Consistent with our previous results, AR could lead to a remarkable decrease in the efficiency of photosynthesis in plants, and proteomic studies demonstrated that Rubisco was decreased under AR stress in Arabidopsis $[10,15]$. On the other hand, it has been reported that the transcription of Calvin cycle enzymes were decreased in drought- and salt-stressed barley [33]. In P. massoniana, phosphoglycerate kinase (spot 53, Table 1) was found to be down-regulated under AR treatment. These results suggest 
that the photosynthesis apparatus is susceptible to AR stress, which may be one of the major reasons for decreased chlorophyll content and photosynthesis under AR stress in P. massoniana (Figure 1B,C). On the contrary, no significant change in AR-stressed T. wallichiana var. mairei leaves (Figure 1B,C), photosynthesis-related proteins including NADH-ubiquinone oxidoreductase $10.5 \mathrm{kDa}$ subunit (spot 1, Table 2), phosphoribulokinase (spot 10, Table 2) and ATP-dependent zinc metalloprotease FTSH (spot 11, Table 2) were increased in T. wallichiana var. mairei under AR treatment. For example, phosphoribulokinase that catalyzes the final step in the regeneration of ribulose-1,5-bisphosphate in the Calvin cycle, was up-regulated by AR in T. wallichiana var. mairei in this study, which was different from what was found in P. massoniana. On the other hand, the expression of ATP-dependent zinc metalloprotease FTSH (spot 11, Table 2), a membrane bound protein located in thylakoids involved in the removal of a damaged D1 protein from PSII in plants, was also up-regulated in AR-treated T. wallichiana var. mairei. These findings indicated that the mechanisms of photosynthetic metabolism under AR stress are different between P. massoniana and T. wallichiana var. mairei. Photosynthesis apparatus is susceptible to AR stress, which may be one of the major reasons for decreased chlorophyll content and photosynthesis under AR stress in P. massoniana. On the contrary, photosynthesis-related proteins were increased in $T$. wallichiana var. mairei under AR treatment, which may compensate the impaired photosynthesis apparatus by AR. Thus, no significant changes in the chlorophyll content and $P \mathrm{n}$ were found in $T$. wallichiana var. mairei under simulated AR treatment, indicating that T. wallichiana var. mairei is more resistant than P. massoniana in response to AR stress. We presumed that $T$. wallichiana var. mairei is an AR-tolerant species with a high capacity for regulating related proteins to enhance photosynthetic metabolism, and inhibit the impaired effect on photosynthesis by AR stress.

Different from photosynthesis, the accumulation of some energy production and conversion related proteins were increased in P. massoniana under AR treatment. Gao et al. reported that ATPase beta subunit and ATPase CF1 beta chain were up-regulated in leaves of wheat subjected to salt treatment [34]. Other evidence also indicates that sufficient ATP is necessary for plant growth, development and response to stress [28]. In P. massoniana, ATP synthase CF1 beta subunit (spot 3, Table 1), putative ATP synthase beta subunit (spot 17, Table 1) and succinate dehydrogenase (ubiquinone) flavoprotein subunit (spot 65, Table 1) were found to be up-regulated by AR stress in our study. These results indicated that more energy is required for reinforcing $P$. massoniana resistance to AR stress. On the contrary, energy conversion-related proteins including ATP synthase beta subunit (spots 3 and 5, Table 2) and ATP synthase CF1 alpha chain (spot 15, Table 2) showed lower expression in response to AR stress in T. wallichiana var. mairei, which suggests different mechanisms of energy production in T. wallichiana var. mairei exposed to AR treatment.

\subsubsection{Stress and Hormone Response Related Proteins}

Reactive oxygen species (ROS), which play a critical role in plant cellular signaling and stress responses, are readily produced by abiotic stresses [35]. Plants can regulate the ROS level through complex mechanisms such as scavenging ROS with ascorbate peroxidase (APX), and glutathione S-transferase (GST). In this study, both APX and GST (spots 10, 13 and 14, Table 1) were increased in abundance in AR-treated P. massoniana. In addition, we found that several other enzymes associated 
with stress and defense were increased in abundance in $P$. massoniana, including membrane-associated salt-inducible protein (spot 51, Table 1). Thus, the up-regulated expression of these proteins implies that the antioxidative defense system was provoked in AR-treated P. massoniana seedlings, and such a consistent induction is likely a consequence of antioxidative reactions in plants under AR stress. We speculate that $P$. massoniana needs to provoke more defense and stress related proteins against AR stress, and does not have similar protein accumulation such as that found in T. wallichiana var. mairei (AR-resistant). These results, together with the complex expression patterns of stress related proteins in both woody plants provide new insights into the relationships between the impacts of AR stress and defense and stress responses.

Plant hormones are not only involved in plant growth and development, but also important in response to abiotic and biotic stresses. Recent studies suggest that environmental stimuli can regulate endogenous gibberellin (GA) level through the changes of enzymes involved in GA biosynthesis and inactivation [36]. In this study, the abundance of gibberellin 2-oxidase (spot 40, Table 1) decreased in P. massoniana under AR stress, which is consistent with our previous results that AR stress led to a decrease in the abundance of gibberellin-responsive protein in Arabidopsis [15], suggesting the important roles of gibberellin 2-oxidase and GA in AR tolerance in P. massoniana. Moreover, the abundance of auxin-responsive protein (spot 47 Table 1) decreased in AR-treated P. massoniana, suggesting that the auxin pathway may play a role in mediating AR-sensitive woody plants responses to AR stress. Isochorismate synthase (ICS) is required to synthesize salicylic acid for plant defense [37]. Furthermore, it has been reported that the salicylic acid signaling pathway is implicated in the modulation of plant responses to AR stress [7]. Our results showed that the abundance of ICS (spot 4, Table 2) was up-regulated only in T. wallichiana var. mairei. Its presence may provide protection against AR stress and possibly endow T. wallichiana var. mairei with greater AR tolerance.

\subsubsection{Signal Transduction Related Proteins}

In this study, three out of four signal transduction-related proteins, including putative signal tranduction protein (spot 25, Table 1), T-cell activation protein phosphatase $2 \mathrm{C}$-like protein (spot 42, Table 1) and calcium-dependent protein kinase (spot 63, Table 1) showed a down-regulated expression in P. massoniana under simulated AR, whereas the abundance of light-mediated development protein DET1-like isoform 2 (spot 2, Table 2) was increased in $T$. wallichiana var. mairei under AR stress. Free cytosolic $\mathrm{Ca}^{2+}$ is a universal second messenger in plants, acting as a mediator of stimulus-response coupling in the regulation of growth, development and responses to environmental stresses [38]. Modulation of intracellular $\mathrm{Ca}^{2+}$ levels is partly regulated by calcium related proteins. In the present study, the expression of caleosin-related protein (spot 8, Table 1) was significantly down-regulated in P. massoniana under AR stress, suggesting that caleosin-related protein plays an important role in response to AR which is consistent with the previous results in Arabidopsis [39]. Previous studies showed that AR impacts on Ca nutrition, which causes alteration in membrane-associated $\mathrm{Ca}$, membrane destabilization and foliar injury of red spruce, thus affecting forest health [40]. In this study, AR also led to the decreased abundance of a probable calcium-binding protein CML30 (spot 52, Table 1), calcium-binding protein CML19 (spot 8, Table 2) and calcium-binding protein KIC-like (spot 17, Table 2) in P. massoniana and T. wallichiana var. mairei under AR stress. This change 
indicates that Ca-binding proteins have a cryptic correlation with AR tolerance, and their roles need to be further analyzed in woody plants. Furthermore, calcium-dependent protein kinases (CDPKs) are implicated as major primary $\mathrm{Ca}^{2+}$ sensors in plants, and CDPK-controlled signaling pathways regulate specific responses to biotic and abiotic stresses. Here, the abundances of CDPK (spot 63, Table 1) was also decreased in AR-treated P. massoniana, suggesting that the modulation of Ca signaling regulators might reduce AR tolerance of $P$. massoniana. These findings indicate that Ca-dependent signal transduction could be an important signal pathway under AR stress in $P$. massoniana and T. wallichiana var. mairei.

\subsubsection{Transcription Related Proteins}

Transcription is the first step in gene expression and a major point of regulation; transcriptional control on the expression of stress responsive genes is crucial for plant response to various abiotic and biotic stresses [28]. Five proteins including maturase K (spot 15), RNA polymerase beta subunit (spots 22, 23), transposase (spot 26) and retrotransposon protein (spot 56) in P. massoniana and three proteins including maturase $\mathrm{K}$ (spots 7, 26), RNA polymerase II C-terminal domain phosphatase-like 1 (spot 24) in T. wallichiana var. mairei were found to change their expression under AR stress (Tables 1 and 2). Maturase $\mathrm{K}$ catalyzes intron removal in RNA precursors and directly affects gene expression at the translation level. The DNA-dependent RNA polymerase (RNAP) is the central enzyme of the transcription cycle, and RNA polymerase beta subunit is one of the subunits composing the RNA polymerase catalytic core. In the current study, it is interesting that maturase K (spot 15, Table 1), RNA polymerase beta subunit (spots 22 and 23, Table 1) and auxin-responsive protein (spot 47, Table 1) were decreased in abundance in P. massoniana under AR treatment. However, the abundances of maturase $\mathrm{K}$ (spots 7 and 26, Table 2) and RNA polymerase II $C$-terminal domain phosphatase-like 1 (spot 24, Table 2) were increased in AR-treated T. wallichiana var. mairei, indicating that transcription related proteins play a critical role in response to AR stress through adjusting of basic genetic processes in plants. In our study, transcription related proteins showed decreases in abundance in AR-treated P. massoniana, whereas the abundance of transcription related proteins increased in AR-treated T. wallichiana var. mairei (Tables 1 and 2). These data suggest that the process of transcription may be different between P. massoniana and T. wallichiana var. mairei in response to $\mathrm{AR}$.

In addition, transposase (spot 26, Table 1) and retrotransposon proteins (spot 56, Table 1) in transcription displayed down-regulated expression pattern in P. massoniana under AR stress. Further works on these proteins in woody plants under AR stress are needed to clarify their functions.

\section{Experimental Section}

\subsection{Plant Materials and Experimental Procedure}

The seedlings of $P$. massoniana and $T$. wallichiana var. mairei were grown in plastic pots containing $12 \mathrm{~kg}$ soil in a greenhouse with a light/dark regime of $16 / 8 \mathrm{~h}$, temperature of $21 / 27{ }^{\circ} \mathrm{C}$ (night/day), relative humidity of $60 \%-70 \%$, a light intensity of $390 \mu \mathrm{mol} \cdot \mathrm{m}^{-2} \cdot \mathrm{s}^{-1}$ photosynthetically active radiation (PAR). The seedlings were sprayed once each day with 
$200 \mathrm{~mL} \cdot \operatorname{pot}^{-1}$ distilled water as control (CK, pH 5.6) or simulated AR solution (AR, pH 3.0). The ion compositions of the $\mathrm{CK}$ solution were adopted from Liu et al., while AR solution was made from CK solution and the $\mathrm{pH}$ was adjusted with a mixture of $\mathrm{H}_{2} \mathrm{SO}_{4}$ and $\mathrm{HNO}_{3}$ in the ratio of 5 to 1 by chemical equivalents, which represents the average ion compositions of rainfall in southern China [10]. The final concentrations of $\mathrm{SO}_{4}{ }^{2-}$ and $\mathrm{NO}_{3}{ }^{-}$were 0.45 and $0.09 \mathrm{mM}$, respectively. After 2-month simulated AR treatment, the sapling needles were collected for physiological measurements and proteomics research.

\subsection{Chlorophyll Content and Net Photosynthetic Rate Measurements}

Plant leaves $(0.1 \mathrm{~g}$ of fresh weight (FW) ) were prepared, and chlorophyll was extracted with ice-cold $80 \% v / v$ acetone. Absorption of the extract was measured at 663 and $646 \mathrm{~nm}$ with a spectrometer (Varian Cary 50 UV-VIS, Varian, Palo Alto, CA, USA) and the chlorophyll content was calculated as described by Wellburn [41].

Leaf net photosynthetic rate $(P n)$ was measured with a portable photosynthesis system (Li-6400, Li-Cor, Lincoln, NE, USA). Air temperature, $\mathrm{CO}_{2}$ concentration, light intensity, and air relative humidity were maintained at $25^{\circ} \mathrm{C}, 380 \mu \cdot \mathrm{L}^{-1}, 800 \mu \mathrm{mol} \cdot \mathrm{m}^{-2} \cdot \mathrm{s}^{-1} \mathrm{PAR}$, and $80 \%$, respectively. At least ten saplings were randomly selected from the $\mathrm{CK}$ or AR treatment group for $\mathrm{Pn}$ measurement.

\subsection{Protein Extraction, 2-DE and 2-DE Gel Data Analysis}

Total proteins were extracted from plant leaves according to the method of phenol extraction [42]. Final washed pellets were vacuum-dried and dissolved in lysis buffer ( $8 \mathrm{M}$ urea, $2 \mathrm{M}$ thiourea, $4 \%$ CHAPS, 1\% DTT, 1\% IPG buffer $\mathrm{pH} \mathrm{4-7)} \mathrm{at} \mathrm{room} \mathrm{temperature.} \mathrm{Three} \mathrm{independent} \mathrm{biological}$ repetitions were performed for each treatment. The protein concentration was determined with a 2-D Quant Kit (GE Healthcare Amersham Bioscience, Little Chalfont, UK) according to the manufacturer's instructions.

Two-dimensional electrophoresis (2-DE) was performed according to $\mathrm{Hu}$ et al. [43]. The sample containing $500 \mu \mathrm{g}$ proteins was loaded onto an IPG strip holder with 18-cm long, $\mathrm{pH} 4-7$ linear (GE Healthcare, Piscataway, NJ, USA) IPG strip, and rehydrated for $18 \mathrm{~h}$ at room temperature. IEF was carried out using an Ettan IPGphor isoelectric focusing system (GE Healthcare Amersham Bioscience, Little Chalfont, UK) as follows: $300 \mathrm{~V}$ for $60 \mathrm{~min}, 600 \mathrm{~V}$ for $60 \mathrm{~min}, 1000 \mathrm{~V}$ for $60 \mathrm{~min}$, a gradient to $8000 \mathrm{~V}$ for $120 \mathrm{~min}$, and kept at $8000 \mathrm{~V}$ for a total of $64000 \mathrm{Vh}$ at $20{ }^{\circ} \mathrm{C}$. After IEF, the IPG strips were equilibrated using an equilibration solution (6 M urea, 30\% glycerol, 2\% SDS, $50 \mathrm{mM}$ Tris- $\mathrm{HCl}, \mathrm{pH} 8.8$ ) containing $1 \%$ DTT for $15 \mathrm{~min}$, followed by $2.5 \%$ iodoacetamide in the same equilibration solution for $15 \mathrm{~min}$. Electrophoresis in the second dimension was performed on $12.5 \%$ SDS polyacrylamide gels using a protean apparatus (Bio-Rad, Hercules, CA, USA) according to the manufacturer's instructions. The gels were stained using Coomassie Brilliant Blue (CBB) (Bio-Rad, Hercules, CA, USA) R-250 and gel images were acquired at 600 dots per inch (dpi) resolution by a scanner (Uniscan M3600, Beijing, China). Three independent gels from each treatment were produced. 2-D gel analysis was performed with PDQuest software (version 7.0, Bio-Rad, Hercules, CA, USA) according to Liu et al. [15]. The protein spots that changed more than two-fold and passed the Student's $t$-test with $p<0.05$ were considered significant. 


\subsection{Protein Digestion and Identification}

In-gel protein digestion and protein identification was followed as described by Liu et al. [15]. Matrix-assisted laser desorption/ionization-time-of-flight mass spectrometry (MALDI-TOF MS) analysis (ReFlexTM III, Bruker, Bremen, Germany) was used to acquire the peptide mass fingerprint (PMF). Standard peptide mixture was spotted adjacent to all samples for external calibration followed by internal mass correction using peptide ions generated by trypsin autoprotolysis $(\mathrm{m} / \mathrm{z} 842.5$, and $\mathrm{m} / \mathrm{z}$ 2211.10). The spectra were analyzed with the flex analysis software (Version 3.2, Bruker-Daltonics, Bremen, Germany). Since the P. massoniana and T. wallichiana var. mairei genome are still unsequenced, a homology-based search was performed. The measured tryptic peptide masses were searched against the National Center for Biotechnology Information non-redundant (NCBInr, Bethesda, MD, USA) database (release date: 16 July 2012), and selecting the taxonomy of green plants using MASCOT interface (Version 2.0; Matrix Science, London, UK). The following parameters were used for database search: $\mathrm{MH}^{+}$monoisotopic mass values, a fragment ion mass tolerance of $\pm 0.3 \mathrm{Da}$, permitting one missed cleavage, alkylation of cysteine by carba-midomethylation as a fixed modification, and oxidation of methionine as a variable modification. MASCOT Peptide Mass Fingerprint (http://www.matrixscience.com) protein scores greater than 73 with the NCBInr database were considered significant $(p<0.05)$. A number of other criteria were further evaluated in the final assignment of protein and peptide identifications: the number of matching peptides (at least four), the coverage (a minimum of $9 \%$ ), and the molecular weight $(\mathrm{Mr})$ and isoelectric point $(\mathrm{p} I)$ of the protein. Furthermore, to avoid false positives, an additional in-house Basic Local Alignment Search Tool (BLAST) search against the NCBI protein database (http://www.ncbi.nlm.nih.gov) was done to reconfirm all the matches.

The identified proteins were used to search for over/under-representation of the searched proteins adopting the AGI codes as input and then searched within the UniProt (Wellcome Trust Genome Campus, Cambridge, UK; Centre Medical Universitaire, Geneva, Switzerland; Georgetown University Medical Center, Washington, WA, USA, http://www.uniprot.org) and TAIR database (Carnegie Institution of Washington Department of Plant Biology 260, Stanford, CA, USA, http://www.arabidopsis.org) to find out if their functions are known, they were then further classified using Functional Catalogue software (Munich Information Center for Protein Sequences, Neuherberg, Germany, http://mips.gsf.de/projects/funcat).

\subsection{Statistical Analysis}

Values in figures and tables were expressed as means $\pm \mathrm{SE}$. The statistical significance of the data was analyzed using a univariate analysis of variance $(p<0.05)$ (Abacus Concepts, Berkeley, CA, USA, one-way ANOVA; SPSS for Windows, version 11.0, SPSS Inc., Chicago, IL, USA).

\section{Conclusions}

In this study, a comparative proteomics analysis was carried out to clarify the differentially expressed protein profiles of two tree species under AR treatment. Our data revealed that many more proteins altered their expression level in P. massoniana than in T. wallichiana var. mairei in response 
to simulated AR treatment. Taken together, metabolism, photosynthesis, signal transduction and transcription related proteins in P. massoniana, a sensitive species, were depressed by AR stress. However, the abundances of proteins participating in photosynthesis as well as in signal transduction and transcription were increased in T. wallichiana var. mairei, a tolerant species, under simulated AR. We presume that AR was a strongly oxidative situation experienced by P. massoniana but was of weak oxidative intensity in T. wallichiana var. mairei. On the other hand, AR stress influenced only part of the photosynthetic network and modified gene expression in such a way as to enhance metabolism systems and strengthen plant defense responses to maintain physiological and biochemical homeostasis in T. wallichiana var. mairei. This is likely one of the reasons $P$. massoniana is more sensitive to AR stress than $T$. wallichiana var. mairei. The proteins identified in this study might be useful in investigating the different defense mechanism of woody plants to AR stress.

Based on the putative functions and expression changes of the identified proteins in P. massoniana and T. wallichiana var. mairei, together with previous reports, we outlined a schematic overview model associated with the different systematic response of $P$. massoniana and $T$. wallichiana var. mairei to AR stress (Figure 5). These results depict a panoramic view of the adaptation strategies in P. massoniana and T. wallichiana var. mairei under AR challenge and deepen our understanding in AR tolerance in woody plants.

Figure 5. A schematic representation of different AR-tolerance mechanisms in P. massoniana and T. wallichinana var. mairei by regulating diverse biological processes. "U" or " $D$ " indicate increase or decrease, respectively.

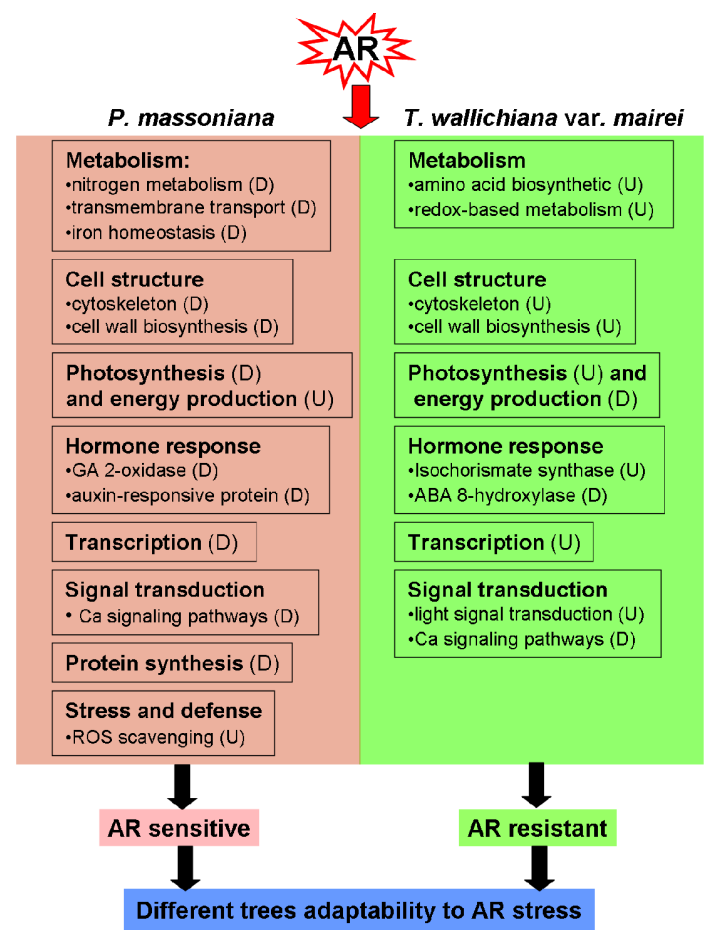

\section{Acknowledgments}

This study was supported by the National Natural Science Foundation of China (NSFC No. 30930076, 31300505, 31260057, 30770192, 30670317), the Foundation of the Chinese Ministry of 
Education (20070384033) and the Program for New Century Excellent Talents in Xiamen University (NCETXMU No. X07115), Zhejiang Provincial Natural Science Foundation (LY13C160014, Z3110443).

\section{Conflicts of Interest}

The authors declare no conflict of interest.

\section{References}

1. Liu, J.; Diamond, J. China's environment in a globalizing world. Nature 2005, 435, 1179-1186.

2. Larssen, T.; Lydersen, E.; Tang, D.; He, Y.; Gao, J.; Liu, H.; Duan, L.; Seip, H.M.; Vogt, R.D.; Mulder, J. Acid rain in China. Environ. Sci. Technol. 2006, 40, 418-425.

3. Likens, G.E.; Driscoll, C.T.; Buso, D.C. Long-term effects of acid rain: Response and recovery of a forest ecosystem. Science 1996, 272, 244-245.

4. Malakoff, D. Taking the sting out of acid rain. Science 2010, 330, 910-911.

5. Fan, H.B.; Wang, Y.H. Effects of simulated acid rain on germination, foliar damage, chlorophyll contents and seedling growth of five hardwood species growing in China. For. Ecol. Manag. 2000, 126, 321-329.

6. Liu, J.; Zhou, G.; Yang, C.; Ou, Z.; Peng, C. Responses of chlorophyll fluorescence and xanthophyll cycle in leaves of Schima superba Gardn. \& Champ. and Pinus massoniana Lamb. to simulated acid rain at Dinghushan Biosphere Reserve, China. Acta Physiol. Plant. 2007, 29, 33-38.

7. Lee, Y.; Park, J.; Im, K.; Kim, K.; Lee, J.; Lee, K.; Park, J.A.; Lee, T.K.; Park, D.S.; Yang, J.S.; et al. Arabidopsis leaf necrosis caused by simulated acid rain is related to the salicylic acid signaling pathway. Plant Physiol. Biochem. 2006, 44, 38-42.

8. Kong, F.; Liu, Y.; Hu, W.; Shen, P.; Zhou, C.; Wang, L. Biochemical responses of the mycorrhizae in Pinus massoniana to combined effects of $\mathrm{Al}, \mathrm{Ca}$ and low $\mathrm{pH}$. Chemosphere 2000, 40, 311-318.

9. Larssen, T.; Carmichael, G. Acid rain and acidification in China: The importance of base cation deposition. Environ. Pollut. 2000, 110, 89-102.

10. Liu, T.W.; Wu, F.H.; Wang, W.H.; Chen, J.; Li, Z.J.; Dong, X.J.; Patton, J.; Pei, Z.M.; Zheng, H.L. Effects of calcium on seed germination, seedling growth and photosynthesis of six forest tree species under simulated acid rain. Tree Physiol. 2011, 31, 402-413.

11. Gao, L.; Möller, M.; Zhang, X.M.; Hollingsworth, M.; Liu, J.; Mill, R.; Gibby, M.; Li, D.Z. High variation and strong phylogeographic pattern among cpDNA haplotypes in Taxus wallichiana (Taxaceae) in China and North Vietnam. Mol. Ecol. 2007, 16, 4684-4698.

12. Liu, K.; Yu, F.; Peng, S.; Fang, Y.; Li, F. Effects of simulated acid on saplings of Taxus species. Ecol. Environ. 2007, 16, 309-312.

13. Liu, J.; Yang, C.; Wang, M. Effect of simulated acid rain on physiological characteristics in Taxus chinensis var. Mairei. Chin. J. Trop. Crop. 2012, 33, 1046-1050.

14. Liu, T.; Jiang, X.; Shi, W.; Chen, J.; Pei, Z.; Zheng, H. Comparative proteomic analysis of differentially expressed proteins in $\beta$-aminobutyric acid enhanced Arabidopsis thaliana tolerance to simulated acid rain. Proteomics 2011, 11, 2079-2094. 
15. Liu, T.W.; Fu, B.; Niu, L.; Chen, J.; Wang, W.H.; He, J.X.; Pei, Z.M.; Zheng, H.L. Comparative proteomic analysis of proteins in response to simulated acid rain in Arabidopsis. J. Proteome Res. 2011, 10, 2579-2589.

16. Wang, X.Q.; Liu, Z.; Niu, L.; Fu, B. Long-term effects of simulated acid rain stress on a staple forest plant, Pinus massoniana Lamb: A proteomic analysis. Trees-Struct. Funct. 2013, 27, 297-309.

17. Chen, J.; Wang, W.H.; Liu, T.W.; Wu, F.H.; Zheng, H.L. Photosynthetic and antioxidant responses of Liquidambar formosana and Schima superba seedlings to sulfuric-rich and nitric-rich simulated acid rain. Plant Physiol. Biochem. 2013, 64, 41-51.

18. Bernard, S.M.; Habash, D.Z. The importance of cytosolic glutamine synthetase in nitrogen assimilation and recycling. New Phytol. 2009, 182, 608-620.

19. Wang, H.; Ahan, J.; Wu, Z.; Shi, D.; Liu, B.; Yang, C. Alteration of nitrogen metabolism in rice variety 'Nipponbare' induced by alkali stress. Plant Soil 2012, 355, 131-147.

20. Yousfi, S.; Serret, M.D.; Márquez, A.J.; Voltas, J.; Araus, J.L. Combined use of $\delta^{13} \mathrm{C}, \delta^{18} \mathrm{O}$ and $\delta^{15} \mathrm{~N}$ tracks nitrogen metabolism and genotypic adaptation of durum wheat to salinity and water deficit. New Phytol. 2012, 194, 230-244.

21. Hanke, G.T.; Kimata-Ariga, Y.; Taniguchi, I.; Hase, T. A post genomic characterization of Arabidopsis ferredoxins. Plant Physiol. 2004, 134, 255-264.

22. Neuhaus, H.; Emes, M. Nonphotosynthetic metabolism in plastids. Annu. Rev. Plant Biol. 2000, $51,111-140$.

23. Ceccarelli, E.A.; Arakaki, A.K.; Cortez, N.; Carrillo, N. Functional plasticity and catalytic efficiency in plant and bacterial ferredoxin-NADP $(\mathrm{H})$ reductases. BBA-Proteins Proteom. 2004, $1698,155-165$.

24. Rodriguez, R.E.; Lodeyro, A.; Poli, H.O.; Zurbriggen, M.; Peisker, M.; Palatnik, J.F.; Tognetti, V.B.; Tschiersch, H.; Hajirezaei, M.R.; Valle, E.M. Transgenic tobacco plants overexpressing chloroplastic ferredoxin-NADP $(\mathrm{H})$ reductase display normal rates of photosynthesis and increased tolerance to oxidative stress. Plant Physiol. 2007, 143, 639-649.

25. Kushnir, S.; Babiychuk, E.; Storozhenko, S.; Davey, M.W.; Papenbrock, J.; de Rycke, R.; Engler, G.; Stephan, U.W.; Lange, H.; Kispal, G. A mutation of the mitochondrial ABC transporter Stal leads to dwarfism and chlorosis in the Arabidopsis mutant starik. Plant Cell 2001, 13, 89-100.

26. Bona, E.; Marsano, F.; Cavaletto, M.; Berta, G. Proteomic characterization of copper stress response in Cannabis sativa roots. Proteomics 2007, 7, 1121-1130.

27. Ravet, K.; Touraine, B.; Boucherez, J.; Briat, J.F.; Gaymard, F.; Cellier, F. Ferritins control interaction between iron homeostasis and oxidative stress in Arabidopsis. Plant J. 2008, 57, $400-412$.

28. Jiang, Y.; Yang, B.; Harris, N.S.; Deyholos, M.K. Comparative proteomic analysis of $\mathrm{NaCl}$ stress-responsive proteins in Arabidopsis roots. J. Exp. Bot. 2007, 58, 3591-3607.

29. Singh, B.; Mishra, R.; Agarwal, P.K.; Goswami, M.; Nair, S.; Sopory, S.; Reddy, M. A pea chloroplast translation elongation factor that is regulated by abiotic factors. Biochem. Biophys. Res. Commun. 2004, 320, 523-530.

30. Jonak, C.; Hirt, H. Glycogen synthase kinase 3/SHAGGY-like kinases in plants: An emerging family with novel functions. Trends Plant Sci. 2002, 7, 457-461. 
31. Wan, X.Y.; Liu, J.Y. Comparative proteomics analysis reveals an intimate protein network provoked by hydrogen peroxide stress in rice seedling leaves. Mol. Cell. Proteomics 2008, 7 , 1469-1488.

32. Ohta, H.; Shibata, Y.; Haseyama, Y.; Yoshino, Y.; Suzuki, T.; Kagasawa, T.; Kamei, A.; Ikeuchi, M.; Enami, I. Identification of genes expressed in response to acid stress in Synechocystis sp. PCC 6803 using DNA microarrays. Photosynth. Res. 2005, 84, 225-230.

33. Ozturk, Z.N.; Talamé, V.; Deyholos, M.; Michalowski, C.B.; Galbraith, D.W.; Gozukirmizi, N.; Tuberosa, R.; Bohnert, H.J. Monitoring large-scale changes in transcript abundance in drought-and salt-stressed barley. Plant Mol. Biol. 2002, 48, 551-573.

34. Gao, L.; Yan, X.; Li, X.; Guo, G.; Hu, Y.; Ma, W.; Yan, Y. Proteome analysis of wheat leaf under salt stress by two-dimensional difference gel electrophoresis (2D-DIGE). Phytochemistry 2011, $72,1180-1191$.

35. Apel, K.; Hirt, H. Reactive oxygen species: Metabolism, oxidative stress, and signal transduction. Annu. Rev. Plant Biol. 2004, 55, 373-399.

36. Magome, H.; Yamaguchi, S.; Hanada, A.; Kamiya, Y.; Oda, K. The DDF1 transcriptional activator upregulates expression of a gibberellin-deactivating gene, GA2ox7, under high-salinity stress in Arabidopsis. Plant J. 2008, 56, 613-626.

37. Wildermuth, M.C.; Dewdney, J.; Wu, G.; Ausubel, F.M. Isochorismate synthase is required to synthesize salicylic acid for plant defence. Nature 2001, 414, 562-565.

38. Hepler, P.K. Calcium: A central regulator of plant growth and development. Plant Cell 2005, 17, 2142-2155.

39. Kim, Y.Y.; Jung, K.W.; Yoo, K.S.; Jeung, J.U.; Shin, J.S. A stress-responsive caleosin-like protein, AtCLO4, acts as a negative regulator of ABA responses in Arabidopsis. Plant Cell Physiol. 2011, 52, 874-884.

40. DeHayes, D.H.; Schaberg, P.G.; Hawley, G.J.; Strimbeck, G.R. Acid rain impacts on calcium nutrition and forest health. BioScience 1999, 49, 789-800.

41. Wellburn, R. The spectral determination of chlorophylls a and b, as well as total carotenoids, using various solvents with spectrophotometers of different resolution. J. Plant Physiol. 1994, 144, 307-313.

42. Carpentier, S.C.; Witters, E.; Laukens, K.; Deckers, P.; Swennen, R.; Panis, B. Preparation of protein extracts from recalcitrant plant tissues: An evaluation of different methods for two-dimensional gel electrophoresis analysis. Proteomics 2005, 5, 2497-2507.

43. Hu, W.J.; Chen, J.; Liu, T.W.; Liu, X.; Wu, F.H.; Wang, W.H.; He, J.X.; Xiao, Q.; Zheng, H.L. Comparative proteomic analysis on wild type and nitric oxide-overproducing mutant (noxl) of Arabidopsis thaliana. Nitric Oxide 2014, 36, 19-30.

(C) 2014 by the authors; licensee MDPI, Basel, Switzerland. This article is an open access article distributed under the terms and conditions of the Creative Commons Attribution license (http://creativecommons.org/licenses/by/3.0/). 